\title{
Argentine Clustering of Soy Biodiesel Production: The Role of International Networks and the Global Soy Oil and Meal Markets
}

\author{
Julia Tomei ${ }^{*}, 1$ and Paul Upham ${ }^{2}$ \\ ${ }^{I}$ UCL Energy Institute, University College London, Central House, 14 Upper Woburn Place, London, WCIH ONN, UK \\ ${ }^{2}$ Tyndall Centre Manchester, University of Manchester, Pariser Building, Sackville Street, Manchester M13 9PL, UK
}

\begin{abstract}
Argentina aspires to become the global equivalent of Brazil for biodiesel and is well placed to do so. With a large, efficient and export-focused agricultural sector, Argentina is the world's third largest exporter of soy and sunflower oils. Growing global demand and, to a far lesser extent, domestic demand for biofuels is contributing to the expansion of soy production and processing in Argentina, much of which is centred around the Paraná River. The Argentine biofuels sector exhibits clustering at both the cultivation and processing levels, but is also strongly dependent on other relationships both nationally and internationally, including research and development linkages with international biotechnology firms and the more economically significant soy oil and meal markets. Although the trend of horizontal and vertical integration is advanced and likely to continue, we argue that clustering, in the sense of geographic proximity, needs to be seen in the context of the value chain. To date, governance of the soy industry has been characterised by declining government intervention in production, processing and export processes. In the absence of strong policy, it has been left to agroindustry to determine the development of the nascent biofuels sector, towards one focused primarily on the export market and leading to substantial gains for some actors in the value chain and losses for weaker players.
\end{abstract}

Keywords: Agroindustry, Argentina, clustering, production networks, soy-based biodiesel.

\section{INTRODUCTION}

At the dawn of the $21^{\text {st }}$ century, the world faces three 'grand challenges': climate change, energy resilience and poverty reduction. Many researchers and policymakers have been quick to emphasise the potential of biofuels to address these three challenges simultaneously and public policy has developed rapidly in response. For example, in Europe biofuels policy is expressed firstly via the Biofuels Directive (2003/30/EC) [1], which requires that 'biofuels or other renewable fuels' constitute 5.75 percent of the energy content of petrol and diesel sold for transport in member states by 2010. The Renewable Energy Directive (2009/28/EC) [2] has extended this target by establishing a mandatory 10 percent target for energy in transport to be from renewables. In the US, the Energy Independence and Security Act of 2007 [3] mandated the consumption of 36 million gallons of biofuels annually by 2022 . Driven largely by energy security concerns, biofuels are viewed by many in the US as essential to reducing dependence on foreign oil by 20 percent within 20 years [4]. China also has a target to 2020, while Australia, Canada, Colombia, Japan, Mexico and South Africa have mandates for bioethanol blends [5].

One consequence of the rapidly growing demand for biofuels has been a shift in focus from the global North to the global South as investors seek higher productivity with lower costs. Many governments and businesses in the South have responded positively to the increased global demand for

\footnotetext{
*Address correspondence to this author at the UCL Energy Institute, University College London, Central House, 14 Upper Woburn Place, London, WCIH OHY, UK; Tel: 0203108 5979; Fax: 0203108 5986;

E-mail 1:j.tomei@ucl.ac.uk
}

biofuels, highlighting the potential that biofuels offer for regional development, job creation and diversified revenue. However, research has shown that often these benefits fail to materialise and may actually lead to worsening social and environmental conditions for many in the developing world [6-9]. In December 2008, the European Parliament agreed that in order to count toward the EU target, biofuels must deliver life-cycle $\mathrm{CO}_{2}$ savings of initially 35 percent, then 50 percent from 2017, rising to 60 percent when produced from new refineries that come on-stream from 2017 onwards [10]. The European Parliament has repeatedly referred to the need for biofuels supply to be subject to effective sustainability criteria, and has specified environmental criteria for this purpose, essentially prohibitions on the use of biodiverse, high carbon stock, and wooded land (Article 17 in [11]).

This paper discusses the clustering of the Argentine soy biodiesel industry, its antecedents and its situation within global soy oil and meal markets, with reference to both its dependence on extended technology and intellectual property (IP) networks and to its vulnerability to sustainability certification in export markets, particularly in Europe. The objective is to illustrate a particular instance of the way in which physical clustering of an economic sector may be set within extended IP networks that simultaneously support economic growth, but at the same time may render an emergent sector vulnerable to distant legislation. Although the Argentine biodiesel industry exhibits clustering at the cultivation and processing levels, this takes place at only certain points of the production chain. Production of Argentine soy biodiesel is dependent on other key relationships both nationally and internationally. Seen from this perspective, clusters can be seen as nodes or regions of resource transformation located in a wider web of 
connections. The remainder of this paper is structured as follows: in section two we draw attention to some of the production networks literature that helps to set clustering in context, prior to describing those relationships in Argentine practice. In section three we outline the materials used and methodology adopted for this study. Section four presents the findings of the study and reviews some of the issues surrounding the nascent biodiesel industry. We finish the paper with some concluding thoughts on the future of the Argentine biodiesel industry, particularly in light of international environmental legislation.

\section{GLOBAL PRODUCTION NETWORKS}

There is a substantial body of conceptual and empirical work on network approaches to the labour and production processes involved in converting resources into end products. Early work on international commodity chains focused on a staple food commodity and capital good of the sixteenth to eighteenth industry: flour and ships [11]. Gereffi and colleagues later approached global commodity chains (GCC) from a political economy perspective [12]. Henderson and colleagues went on to argue that the concept of global production networks (GPN) offered a new way of understanding globalisation [13], particularly the way in which institutions and interest groups operate at multi-scalar levels [14]. In this and related work, networks are used as the basic unit of analysis, rather than firms. The aim is thus to understand economic activity and power or agency as a relational process rather than as simply located in organisational forms or structures. By seeing firms from this perspective, the strategic economic role of a wide range of factors and organisations is more clearly evident.

The networks approach has been used extensively in analysis of the agricultural sector, highlighting (simply to illustrate the breadth of topics): the linkages between international consumption and the local, socio-economic impacts of contract farming [15]; opportunities for developing countries to upgrade from buyer-driven relationships towards a position in which producers have more control [16]; the importance of non-human actors or factors in understanding production-consumption networks [17]; how agricultural standards and certification interact with existing political economic structures and conventions [18]; the unexpected power of contract farmers in Honduras, producing for the Asian market [19].

Our premise is that understanding clustering in the Argentine soy biodiesel case requires attention not only to local economic and spatial factors - notably the distribution of human and non-human resources - but also to the extended value and supply chains that frame the more obvious and visible geographical proximity. These factors, often geographically remote from the physical clusters themselves, both support the clustering and potentially through the possibility of the withdrawal of that support pose a risk factor. For this reason we need to understand key factors in the extended soy biodiesel value chain, in addition to the regional natural resource base and socio-economics.

\section{MATERIALS AND METHODOLOGY}

Methodologically, the paper is a case study of an Argentine economic sector involving, as a means of enquiry, exploration, description and explanation [20-22]. This study is an in-depth description of a specific context and situation. As such, it illustrates trends and issues that are both intrinsically of interest and that may be explored in further work, be these additional case studies for comparison or larger-scale, more quantitative work.

The materials used are documentary evidence obtained as part of a wider assessment of the environmental and social sustainability of Argentine biodiesel production [23, 24]. The empirical component of this paper is based on stakeholder interviews that were carried out in Argentina between July and August 2008. This qualitative evidence is supported by the review of relevant academic and grey literature. A total of 19 depth interviews were held with stakeholders from government (4), academia (6), farmer's organisations (2), the biofuels industry (3) and NGOs (4). Stakeholders were chosen for interview on the basis of their involvement in the biofuel and/or agricultural sectors. The opinions and attitudes of the stakeholders towards the nascent biodiesel industry were diverse and often highly polarised. Some, principally those representing industry and farmers, argued that biodiesel represented an exciting opportunity which Argentina was uniquely placed to capitalise on. Others, however, expressed concern that the additional demand for soy, created by the developing biodiesel industry, would lead to further expansion of the agricultural frontier, leaving rural communities and the environment to bear the brunt of this expansion. All interviewees expressed concern that an appropriate governance framework to mitigate the negative impacts of the developing industry had yet to be developed. In producing this paper, we recognise that our positionality (that is to say our values, positions, framing of the research question and interpretation of the data) means that this research cannot be value free and objective; however, by interviewing stakeholders from across several sectors, and supported by grey and academic literature, we have attempted to minimise researcher bias.

\section{RESULTS}

Despite being a relative newcomer to the biofuels industry, Argentina is well placed to meet growing international demand for biofuels, particularly for biodiesel [25]. Globally, Argentina is one of the top three producers and exporters of vegetable oil and is the largest global exporter of both soy and sunflower oils [26, 27]. The soybean (Glycine max) is the principal feedstock of the developing biofuels industry in Argentina. Although research is being carried out into other possible feedstocks, such as Jatropha curcas and algae, soy is likely to remain the industry's principal feedstock for the foreseeable future. Clustering occurs at both the cultivation and processing levels; with the majority of the biodiesel sector located in the central Pampas region, enabling easy access to the Paraná river- a waterway with deep water suitable for large, export bound vessels (Fig. 1).

\subsection{The Argentinean Policy Context}

No sector-specific policy can wholly be understood without its political and economic context and this is very much the case for Argentina, a resource-rich country with a land area some 11 times that of the UK but two thirds the 
population. Argentina's economy is relatively, but not solely, dependent on commodity exports, with primary goods and processed agricultural products constituting some 57 percent of export value in 2007, and with manufactured output constituting some 31 percent of export value in the same year [29].

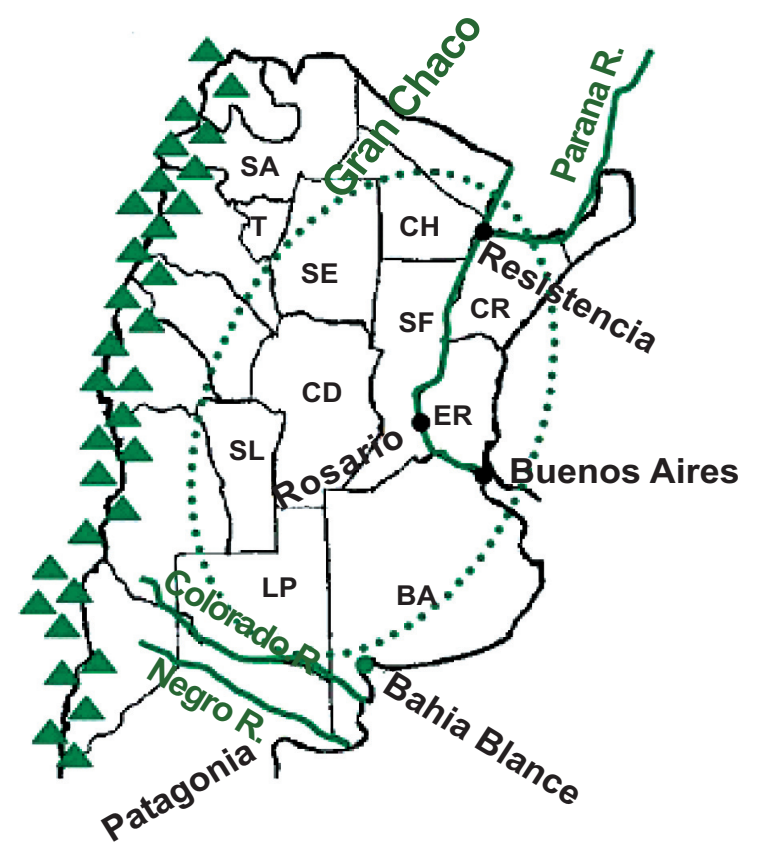

Fig. (1). Argentina's crop production areas. Source: [28]. Major rivers and ports are indicated. There are 23 provinces in Argentina, this figure shows only the key soy producing provinces. Guide to provinces: $\mathrm{BA}=$ Buenos Aires, $\mathrm{LP}=$ Las Pampas, $\mathrm{SL}=\mathrm{San}$ Luis, $\mathrm{CD}=$ Córdoba $; \mathrm{ER}=$ Entre Ríos, $\mathrm{SF}=\mathrm{Santa} \mathrm{Fe}, \mathrm{SE}=$ Santiago del Estero, $\mathrm{CR}=$ Corrientes, $\mathrm{CH}=$ Chaco, $\mathrm{SA}=$ Salta, $\mathrm{T}=$ Tucumán.

Following the election of Peronist candidate, Carlos Menem in 1989, liberalising policies were pursued that pegged the currency to the US dollar, deregulated commerce, privatised industry, and reduced social programmes, instituted in return for assistance by the International Monetary Fund [30, 31]. A decade of rapid economic growth was followed by economic collapse in late-2001, when the accumulation of international debt failed to be offset by short-term injections of government revenues from the sales of state enterprises and the fortuitous expansion of foreign markets [31]. Until the 2008 global financial crisis, high global economic growth had kept commodity prices high and had helped stave off further turmoil [23]. With contracting global growth, a high national debt and domestic inflation, exports of grains, cattle and agricultural commodities will likely remain vital to the national economy.

The liberalising policies of the 1990s have resulted in a weakened role for the state. In the agricultural sector, the absence of agrarian policies and strategies has allowed the market to determine the direction of agricultural development, leaving the sector vulnerable to fluctuations in external markets. Furthermore, the government's noninterventionist policies have allowed companies to integrate vertically, although this situation is by no means unique to Argentina. Today, just a handful of companies dominate virtually every aspect of biodiesel production in Argentina, from feedstock cultivation to processing and distribution.

\subsubsection{Biofuel Policy In Argentina}

In May 2006, Argentina passed a law mandating that biofuels (both bioethanol and biodiesel) account for 5 percent of all fuel sold by 2010 (Régimen de Regulación y Promoción para la Producción y Uso Sustentables de Biocombustibles, Law No. 26.093/06 [32]). The law will create demand for an estimated 625,000 tonnes of biodiesel and 160,000 tonnes of bioethanol [33]. One estimate suggests that this domestic demand can be met with just 8-9 percent of national vegetable oil production and 2 percent of corn production [26]. However, there is concern that the increased demand for biofuels will driver further expansion of the agricultural frontier, thus diminishing potential greenhouse gas (GHG) savings [e.g. 23, 34].

There are three potential markets for Argentinean biodiesel: autoconsumo (usually translated as selfconsumption), domestic and export. While producers who supply either the autoconsumo or the domestic market will benefit from tax and other investment incentives, those who supply the export market will receive no such incentives [35]. Various provincial laws have also been ratified to promote the production of biofuels and encourage investment in the regions [26].

At present, there is disparity between the sector the Biofuels Law is trying to promote - primarily the autoconsumo and domestic markets - and the sector that is developing. The domestic market has little appeal for the large companies - primarily the vegetable oil refiners and agribusiness - that currently dominate the sector and that are interested in the more profitable export markets. Several factors may explain the lack of interest in the domestic market: firstly, government delayed determining a price for domestic biofuels, which has made it impossible for producers to estimate their profit margins. Secondly, the low domestic price of transport fuels due to subsidies meant that there is no domestic demand for alternative transport fuels, including biofuels. In the absence of subsidies it is unlikely that biofuels will be cost-competitive with traditional fuels. Finally, although the government has provided demand guarantees, this assurance is worth little in the current economic and political climate where distrust in government is widespread. Therefore, investors remain unconvinced that the domestic market represents a viable alternative to the export market and the development of plants to supply the internal market has been slow [23].

The biofuel mandate came into force on the $1^{\text {st }}$ January 2010 but, at the time of writing, Argentina's service stations had yet to begin supplying the blended diesel. Analysts had predicted that implementing the mandate would result in a 5 percent increase in the price of diesel at the pump, with the result that Government had yet to indicate a price for the blended diesel and none was being sold [36].

\subsection{The Soy Biodiesel Chain}

In the world of agricultural commodities, the soybean value chain is distinctive as it consists of an input commodity (soybean) that can be processed into two, more valuable, output commodities (soy meal and oil) that are sold 
in separate and independent markets [37]. National and international demand for biodiesel has provided those involved in the soy industry (e.g. farmers, agribusiness and oilseed crushers) with another market opportunity, which has led to the rapid development of the biodiesel industry in Argentina (Fig. 2). Here we consider the production chain for Argentinean soy biodiesel, tracing it through feedstock cultivation, transportation, processing and conversion to export.

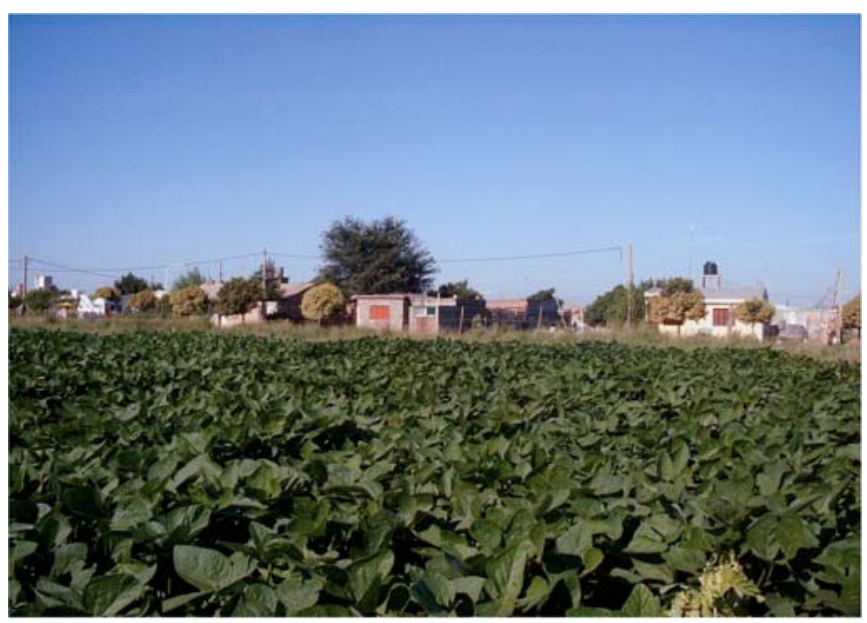

Fig. (2). Soy cultivation, Entre Ríos (photo: Semino).

\subsubsection{Soy Feedstock Cultivation}

Writing in 1971, Eduardo Galeano [38] argued that yields of wheat, corn and cotton were lower in Argentina than in developed countries, because Argentinean landowners showed no interest in technical innovations. Galeano maintained that productivity was low because it suited the landowners who preferred to increase profits by extending their estates, rather than apply modern intensive techniques. Following the structural adjustment policies of the 1990s, and the opening of Argentina's export economy, the situation today looks very different. Agriculture in Argentina is characterised by the rapid adoption and diffusion of new technologies and knowledge. The presence of major international agribusiness companies has also led to dramatic increases in agricultural inputs and the use of technology, in particular GM crops. This capacity to assimilate new knowledge has been vital to the competitiveness of the soybean industry.

Traditionally, agricultural production has been clustered around the fertile central Pampas, a wide plain of more than 58 million hectares (Mha) that is highly suitable for livestock husbandry and crop production. The majority of Argentina's crop area is today located within $300 \mathrm{~km}$ of the ParanáParaguay waterway or a major port (Fig. 1). In recent years, high international prices for agricultural commodities, combined with infrastructure developments, have made it profitable to cultivate virgin or marginal lands and production is extending towards the north and northwest of the country (Table $\mathbf{1}$ ).

During the 2008/09 growing season, an estimated 32Mha were cultivated in Argentina; the production of soy accounted for more than 50 percent of the total area (Fig. 3 ) [27]. The area planted with soy has increased rapidly since the 1970s: from less than 1 Mha in $1970 / 71$, to 6.9 Mha in $1996 / 97$ (the year GM soy was introduced), to 16.6Mha in $2007 / 08$ [29]. Although a severe drought during the 2008/09 growing cycle led to dramatically reduced yields in the Pampas, analysts expected Argentina's soy area to rise even higher during the 2009/10 season to reach a record between 19-20Mha [40].

The rapid increase in soy production has not only been due to agricultural expansion, but also due to increasing yields. Between 1970 and 1995, average yields increased from $1,400 \mathrm{~kg}$ per hectare $(\mathrm{kg} / \mathrm{ha})$ to $2,200 \mathrm{~kg} / \mathrm{ha}$. Since the adoption of GM soy in 1996/97, yields have increased further and in 2008 reached $2,826 \mathrm{~kg} / \mathrm{ha}$ [27].

In Argentina, as in other parts of the world, technological advances have enabled the development of new production systems. For soy the use of a technological package, consisting of GM seed, glyphosate (the herbicide to which GM soy is resistant) and no-tillage practices, has led to the consolidation of an agricultural model based on mechanised,

Table 1. Soy Production by Province (Million Tonnes Per Annum)

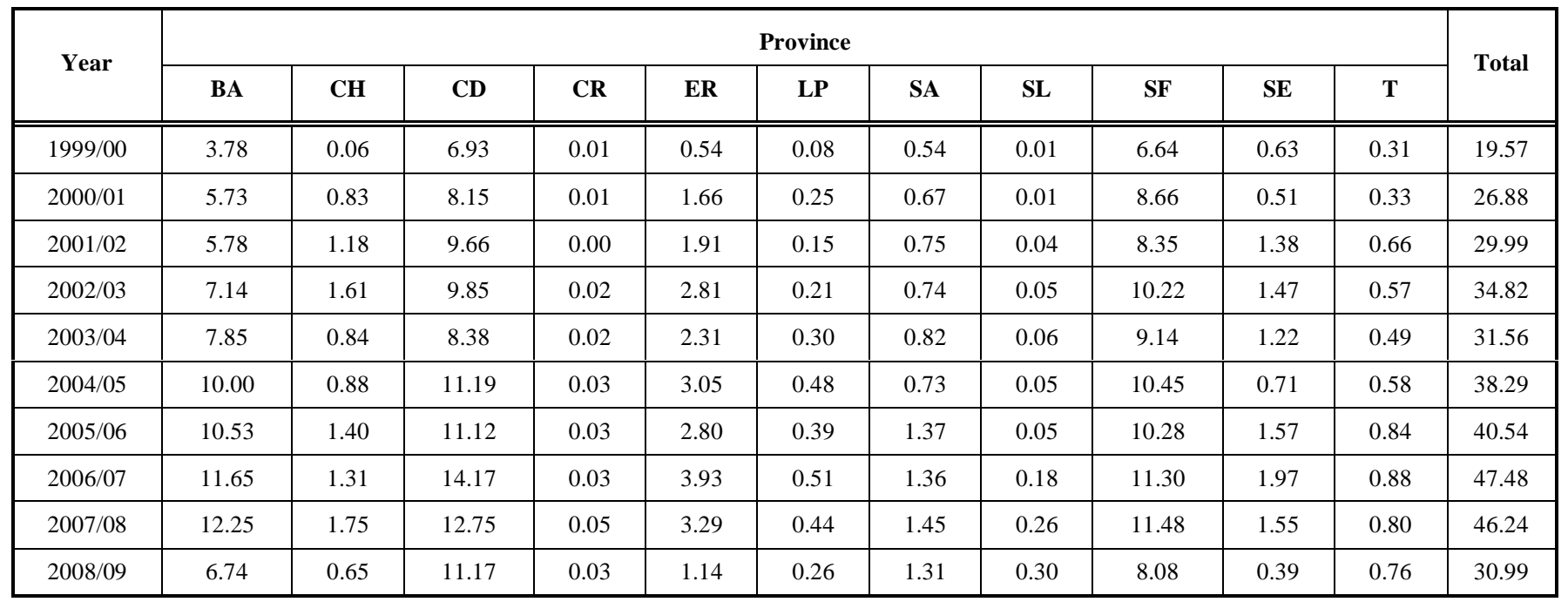

Source: [39]. There are 23 provinces in Argentina; this table shows only the key soy producing provinces. Guide to provinces: BA = Buenos Aires, LP = Las Pampas, SL = San Luis, $\mathrm{CD}=$ Córdoba ER = Entre Ríos, $\mathrm{SF}=$ Santa Fe, $\mathrm{SE}=$ Santiago del Estero, $\mathrm{CR}=$ Corrientes, $\mathrm{CH}=\mathrm{Chaco}, \mathrm{SA}=\mathrm{Salta}, \mathrm{T}=\mathrm{Tucumán}$. 


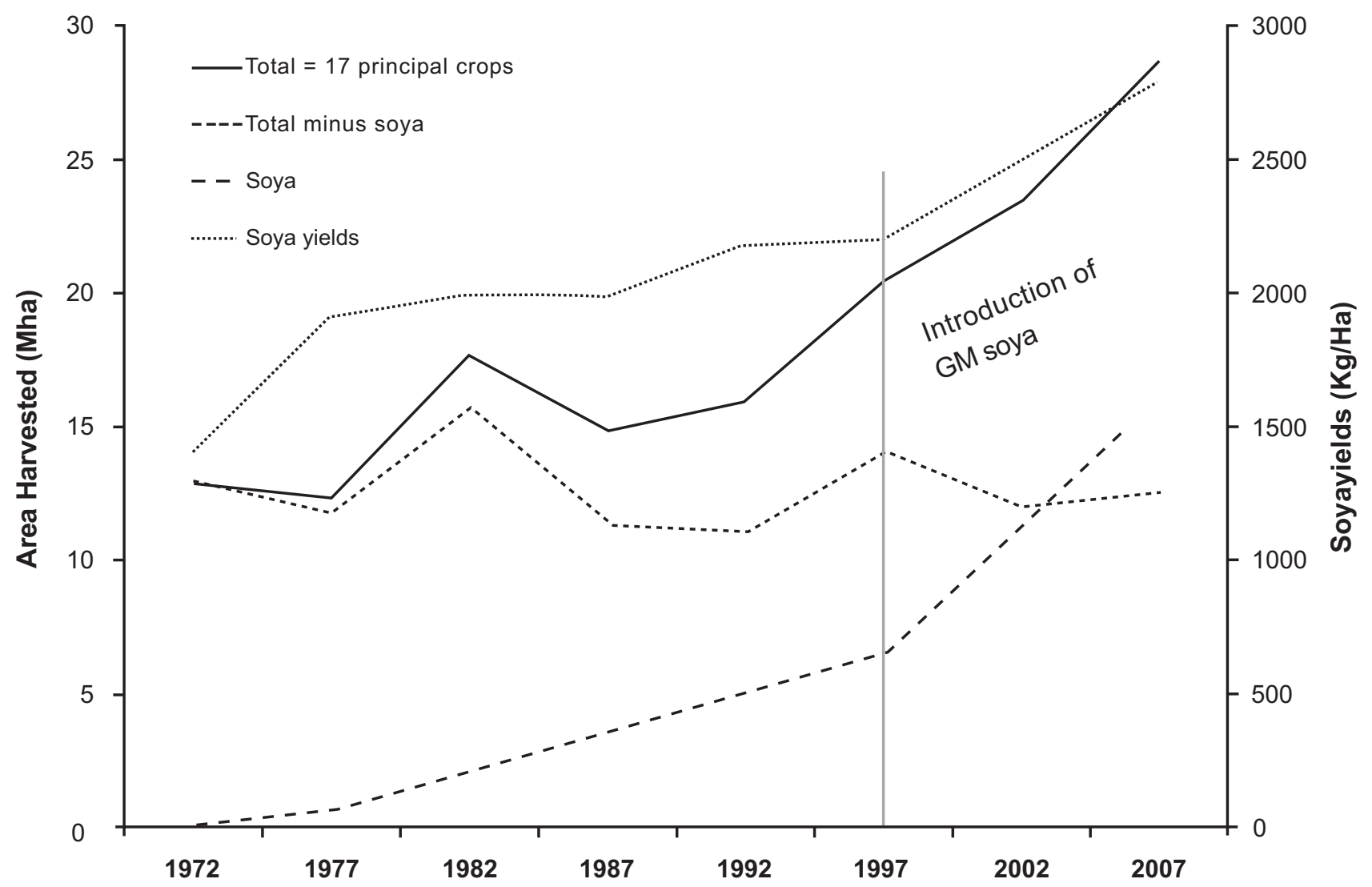

Fig. (3). Evolution of agricultural production, 1972 to 2007. Source: [27]. The primary axis shows the area harvested, while the secondary axis displays yields of soya between 1972 and 2007. Total = 17 principal crops (barley, birdseed, flax, green beans, maize, millet, rapeseed, rice, rye, safflower, sorghum, soya, sugarcane, sunflower, tea, wheat and yerba mate). The introduction of GM soya in 1996/97 is indicated.

large-scale production that is focused on export markets. In addition, lower prices for agricultural commodities caused by export taxes, have forced farmers to increase their efficiency. Nonetheless, farmers are increasingly choosing to produce soy over other crops due to higher gross profit margins. In particular, the reduced need for fertiliser means that soy production requires less capital and investment per surface area [26].

\subsubsection{Transportation and Storage}

In Argentina, the vast majority (91 percent) of agricultural produce is transported by truck; transportation by rail accounts for just 8 percent and barge only 1 percent [41]. The Argentine railroads were privatised during the 1990s, but there has been little investment in rail infrastructure and while the trucking syndicates, key supporters of the governing Peronist Partido Justicilalista party, remain influential the necessary investment in rail seems unlikely [42]. Reliance on expensive transportation by truck to move agricultural commodities to export positions has resulted in farm-to-port charges that remain closely coupled to the cost of fuel [28]. The Rosario Stock Exchange estimates that transportation by truck is 60 percent higher than by train, although this is compensated to some extent by the flexibility of this mode of transport, especially for distances of less than $300 \mathrm{~km}$ [43]. Seasonality in transport demand - with periods of high demand coinciding with the harvest - has disincentivised investment in the transport fleet and the average age of the fleet is estimated at 20 years [41].

Prior to the introduction of silo bags in 2003/04, the greatest bottleneck in Argentina's logistic system was its limited storage capacity, which led to significant delays during harvesting with trucks waiting to unload their cargoes. Silos are typically able to hold up to 210 tonnes of soybeans for up to one year and, since grains are stored in a hermetic environment, have reduced storage losses [44].

\subsubsection{Soy Processing and Conversion}

The crushing industry processes soybeans to release the two main components of soy: the soy oil (20 percent by dry weight) and the soy protein (43 percent by dry weight) (the remainder of the soybean being composed of carbohydrates and minerals). Significant private investment in the crushing sector means that Argentina now has the largest soy crushing industry in the world: the 2008/09 soybean crushing capacity was 32.5 million tonnes and was expected to reach 37 million tonnes in 2009/10 [45]. No other region in the world is capable of this output, an important advantage for the industry. The port complexes of San Lorenzo/San Martin and Rosario are together responsible for shipping 75 percent of soybeans and 97 percent of soy oil bound for export [45].

This highly competitive agroindustrial complex is clustered around the river Paraná, and in particular in the 
province of Santa $\mathrm{Fe}$, close to key production areas and loading ports, which enables easy access to export markets (Figs. 1, 4). The privileged location of the industrial processing industry has increased the competitiveness of the soy value chain, which benefits from shared proximity to location-specific factors, including specialised human capital and infrastructure. Furthermore, the vertical integration and interdependence of actors in the soy production chain has led to the creation of this powerful 'soy cluster', the independence of which is attributed with enabling Argentina's interior to make a fast recovery from the 2001 economic crisis [26].

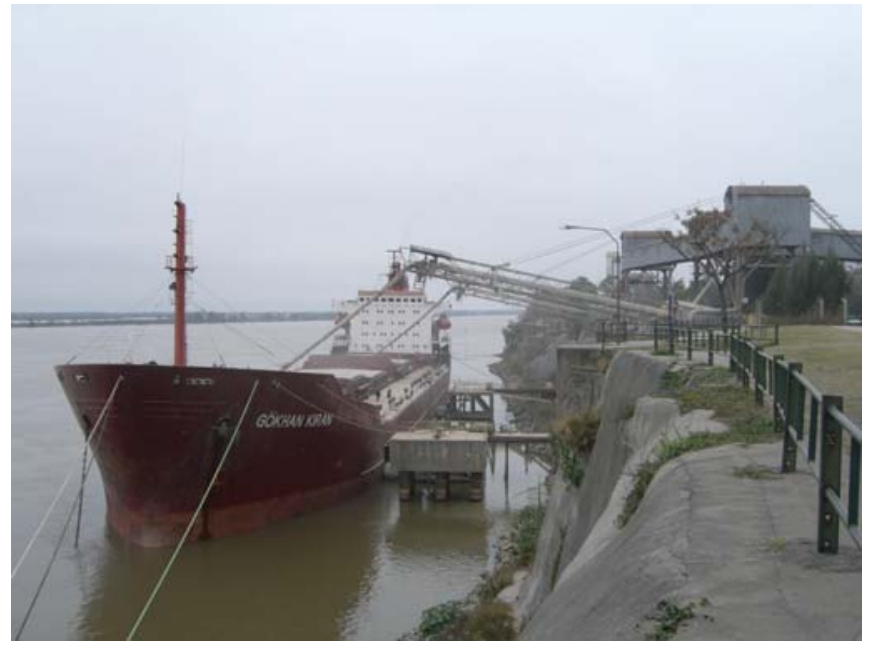

Fig. (4). Soy grains being loaded for export, Paraná River (photo: authors' own).

Increasing global demand for biodiesel has offered new opportunities for vegetable oil refiners by providing another potential market for soy derivatives. This additional market provides these companies with a hedge against price fluctuations - when the price of soy oil falls, refiners switch to biodiesel and vice versa [46] - and the major investments in the Argentine biodiesel industry to date have been made by the vegetable oil refiners [33]. CAdER [47] argues that "clustering and efficiency like this doesn't exist in any other biodiesel market in the world and this is unlikely to change as long as first generation biodiesel remains popular".

\subsubsection{Exports}

There is substantial global demand for Argentinean soy and its derivatives, which include soy meal (used as animal feed), soy oil and soy biodiesel. Until the emergence of global demand for biofuels there was little domestic demand for soy in Argentina; the cattle industry is principally grass fed, the poultry and pork industries are relatively small, and there is not much demand for soy products amongst the local population. Therefore, the vast majority (95 percent) of soy produced in Argentina is exported [44]. A quarter is exported as soybeans with the remainder as soy meal, oil and, more recently, as biodiesel [48]. At present, Argentina is the world's biggest exporter of soybean products, exporting more than 93 percent of its soymeal and 99 percent of its soy oil $[44,48]$. As a result of the growing biodiesel industry, a reduction in exports of soy oil is expected; domestic consumption of soybean oil was forecast to reach 2.5 million tonnes in 2009, largely due to the 2 million tonnes that was expected to be used by the biodiesel industry [45]. The location of the crushing industry either at the port or along a major transportation line to a port gives Argentina an advantage over other major exporters.

Export taxes are used by governments across the globe to achieve a number of public policy objectives such as revenue generation, ensuring supply for domestic markets, keeping food prices stable, and incentivising value-added products. In Argentina, taxes on soy products are estimated to contribute around 12.5 percent of the federal government budget [49]. Exports of soy from Argentina are subject to differential export taxes (DETs), which place lower taxes on processed products (e.g. soy biodiesel) than on the unprocessed product (e.g. soy beans), and thus drive investment towards value-added products. Soybeans are currently taxed at 36 percent, soy oil and meal at 32 percent, and biodiesel at 20 percent (with a 2.5 percent tax deduction, hence a 17.5 percent export tax) [50]. By reducing the costs of the raw material for Argentinean processors, DETs in effect create a strong economic incentive that encourages the production and export of processed soy products, especially biodiesel. However, although at present export taxes favour the production of biodiesel, the sector is vulnerable to changes in taxes that may reduce profit margins.

\subsection{Biodiesel Production Capacity}

In 2008, Argentina produced 7 percent of the world's biodiesel with sales in excess of US\$1.5billion [33]. This made it the world's fourth largest biodiesel producer after Germany (20 percent of global production), the US (16 percent), and France (13 percent) [51]. The situation is fluid however; for example, in 2008 Germany's biodiesel output collapsed due to a biodiesel tax and US 'splash and dash' imports [52].

The total installed capacity increased by 150 percent between 2007 and 2008 and by the end of 2009, production capacity was expected to reach 2.4 million tonnes [33]. Early estimates of production capacity for 2010/11 were obviously contingent on future demand and the investment climate, but production was expected to increase to almost 4 million tonnes (Table 2). However, the global economic crisis has thrown doubt on the development of some planned biodiesel plants.

Investment in the biodiesel sector was estimated to reach US\$2.2 million dollars, with the largest investments made to date being undertaken by vegetable oil refiners, Repsol YPF (an oil company) and food processing companies [26]. In 2008, the main vegetable oil refineries (Vicentín, Renova, Ecofuel, LDC Argentina, and Molinos Río de la Plata) had a combined installed capacity of 850,000 tonnes per year; many of these plants were built with foreign technology [33].

The vast majority of biodiesel plants, particularly those producing biodiesel for export markets, are currently located in just a handful of provinces, all of which are in close proximity to the existing processing industry (Table 2). The province of Santa Fe currently has the greatest concentration of biodiesel production facilities, accounting for 85 percent of the total production during 2008 [36]. This province also processes 87 percent of soybean grain, followed by Córdoba with 8 percent and Buenos Aires with 5 percent [26]. Substantial investments in biodiesel plant were expected in 
Table 2. Argentine biodiesel capacity by province, 2006-2011

\begin{tabular}{|c|c|c|c|c|c|}
\hline Province & 2006 & 2007 & 2008 & 2009 & 2010 \\
\hline Buenos Aires & 70,000 & 70,000 & 142,000 & 242,000 & 542,000 \\
\hline San Luis & 30,000 & 60,000 & 60,000 & 60,000 & 60,000 \\
\hline Córdoba & - & - & - & 260,000 & 260,000 \\
\hline Santiago del Estero & - & - & - & 100,000 & 100,000 \\
\hline Total & 155,000 & 585,000 & $1,424,700$ & $2,406,700$ & $3,946,700$ \\
\hline
\end{tabular}

the province of Córdoba during 2009 [33]. The location of this biodiesel production cluster is not coincidental as it offers considerable advantages for industry, namely its close proximity to ports and key areas of soy production.

\subsection{Supply Chain Actors}

At present, the biodiesel industry is dominated by the vegetable oil refineries who are principally interested in large-scale production for the export market. Three Argentinean companies - Aceitera General Deheza (AGD), Molinos Rio de la Plata and Vicentín - and three multinational commodity companies - Bunge, Cargill and Dreyfus - currently dominate the processing industry, together accounting for 85 percent of the processing capacity [36]. Many of these companies have invested substantially in the biodiesel industry, many of them via joint ventures [53]. Vegetable oil refineries inevitably have strong links to the agricultural sector, with many also providing farmers with agricultural inputs such as agrochemicals and seed. AGD, Molinos, and Vicentín are also soy producers. The contribution of the refineries to GDP and their dominance in the agricultural sector means that these companies are able to exert a strong influence over the direction of biofuels development and policy [23].

Amongst farmers and farmers' associations there is widespread interest in the new opportunities that biodiesel offers. Argentina has a large and powerful farming industry; an influence illustrated by the 2008 dispute with the Government over tax hikes on exports, which led to widespread protests and a political crisis. Although farmers' associations have traditionally represented very different factions, divided as they were by geography, scales and modes of production, and ideology, today their interests are more closely aligned as many of their members switch to producing soy. Farmers' associations, such as ACREA (Regional Consortia for Agricultural Experimentation) and AAPRESID (Association of No Till Producers), work in partnership with both public and private research and development (R\&D) organisations on the development of new crops, processes and technologies and in providing extension services to farmers [23]. Collaboration between private and public research organisations, such as INTA (the National Institute of Agricultural Technology), is also characteristic of Argentina's agricultural sector, with
Argentinean farmers playing a key role as users and adopters of innovations.

One consequence of Argentina's increasingly exportoriented agricultural sector has been the concentration of land ownership. Since the 1990s, state policies have favoured larger producers: between 1992 and 2002 an estimated 60,000 small farmers left agriculture [54] and in the 2007 harvest, 60 percent of the soy harvested was produced by just 4 percent of farmers [55]. Increasingly, however, the new modes of agricultural production are not based on land ownership but on leasing land. An estimated 55 percent of grains produced in the Pampas are by farmers who lease the land [34], as farmers who are unwilling or unable to take the production risk rent out their land to others including neighbours, contractors or investment trusts, who manage production from year to year. Although there are different types of contracts, they are typically short termmany for just one agricultural year. At present, the biggest farmers in Argentina are groups such as Los Grobo and El Tejar, which lease land and contract services from third parties. Many agribusiness companies - both national and international - are also vertically integrated throughout the supply chain, providing for example, agrochemicals, management and financial services and grain trading.

Another key stakeholder is the public research institute, INTA, which provides agricultural extension services to farmers across the country, such as increasing farmers' access to technology. With regards to bioenergy, INTA has a dedicated research programme - the National Programme on Bioenergy - which, amongst other objectives, aims to generate the scientific and technical information to help inform decisions about bioenergy, not just biofuels, in both the private and public sector [56]. By supporting farmers and providing technical services, INTA therefore provides an important role in the development of the nascent biodiesel industry [46].

The government body responsible for promoting the use of biofuels (and not just biodiesel) within Argentina is the National Biofuels Commission. The Commission is comprised of representatives of each of the departments associated with the production of biofuels: the Secretariat for Agriculture, the Secretariat for Energy, and the Secretariat for Environment and Sustainable Development. The Biofuels Commission is responsible for coordinating national policy, 
promoting research into alternative feedstocks, supporting rural biofuel development, and for encouraging investment in the biofuels sector.

Industry represents another important stakeholder in the soy biodiesel value chain. The policies of economic liberalisation, pursued by Menem in the 1990s and deepened by his successors, have enabled transnational corporations (TNCs), such as Monsanto, Cargill and Dreyfus, to become both horizontally and vertically integrated in the Argentine soy production chain. This means TNCs have considerable influence over all stages in the supply chains, as well as over the institutions that govern them [57]. Globally, mergers, acquisitions and business alliances have enabled the consolidation of the agroindustry and just a handful of TNCs now dominate; in 2003, 70 percent of the global agrochemical market was controlled by just five corporations (Monsanto, Syngenta, Dupont, Bayer Crop Science and Basf) and, together with Dow Agroscience, these companies controlled the entirety of the global genetically modified (GM) seed market [57]. One possible reason for the increased dominance of private sector research is the insufficient capacity of public sector research in Argentina (as is the case in many countries); the R\&D budgets of many TNCs are greater than public sector R\&D budgets. Furthermore, greater participation in global commodity markets has increased access to innovations and agricultural inputs, and the intellectual property, technological innovations and capital that many of TNCs embody have been instrumental in the development of the current agricultural model in Argentina.

The oil industry is also involved in the biodiesel industry as the Biofuels Law requires them to buy biodiesel and bioethanol at a price established by government.

\subsection{Local Impacts of International Environmental Legislation}

In terms of the sustainability performance of the Argentinean biodiesel industry, it is the production of the soy feedstock accounts for the majority of the negative impacts. A 2008 study by Panichelli et al. [58] found that the 'agricultural phase' of soy accounted for around 80 percent of global warming potential, largely due to the impacts of land use change. The expansion of agriculture into nontraditional production areas has involved the transformation of native habitats (particularly in four Northern provinces: Santiago del Estero, Chaco, Tucuman and Salta), which are home to some of Argentina's most biodiverse areas. The expansion of soy into these provinces has been attributed to several factors including changes in climate, socio-economic drivers (such as international demand and domestic policy changes) and technological innovation (including GM soy), which have removed many of the constraints that restricted agricultural cultivation in these previously marginal areas [59]. In the agricultural heartlands of Argentina, a major limitation on crop production is the fragility of the soils to both wind and water erosion. Traditionally, cattle and crop production have been combined to address these constraints, but farmers are abandoning traditional rotations as intensive crop production becomes more profitable [60-62]. The increased use of agrochemicals is also having negative impacts on soil and water quality and is affecting the health of local communities [23, 63]. The Argentine NGO, Grupo de Reflexión Rural (GRR), has documented high incidences of cancer, respiratory illnesses and foetal abnormalities amongst rural communities living near to soy fields [63]. However, there is a lack of official data on the impacts of pesticides on human health and the Argentinean health system records only acute poisoning. Therefore, most of the documentation regarding the long-term impacts of exposure to agrochemicals comes from health practitioners, the media, and affected communities and is largely anecdotal [64].

While the involvement of TNCs in agroindustry has undoubtedly brought benefits for some - Argentina has one of the most economically efficient agricultural sectors in the world - for others their involvement has entailed significant risks. The shift from public sector dominance of agricultural research to dominance by private interests has changed the direction of research, as the private sector is motivated by profits and characterised by short-term gains and secrecy [65]. A recent letter to Scientific American [66] expressed concern about the lack of transparency in research on GM crops, wherein researchers must ask seed companies permission before publishing independent research. The author argues that this secrecy makes it impossible to verify the claims that GM crops perform as advertised. Other concerns relate to the dependence of the Argentinean agricultural sector (and the wider economy) on foreign capital, marginalisation of traditional agricultural systems (leading to food insecurity and loss of livelihoods and traditional knowledge) and misuse of market power by TNCs [67]. Within Argentina, there are fears that the dominance of TNCs - and not just those in the agricultural sector - is another form of neo-colonialism.

\section{DISCUSSION AND CONCLUSIONS}

In the Argentine context, as described above, the soy production and refining clusters are embedded in and dependent on particular international intellectual property rights relating to biotechnology, large-scale capital intensive agricultural machinery, and corresponding agronomic practice. All of these have their history and economic bases in North America, while the end market for the more recent biofuel sector is currently located in newly-mandated European demand. At issue is whether these are economically sustainable in the long term, given increasing environmental protection, particularly from Europe. Most notably, biofuels must deliver initial life-cycle $\mathrm{CO}_{2}$ savings of 35 percent in order to count toward the EU biofuel target [10]. Default values for the GHG balance of soy biodiesel in the carbon and sustainability reporting methodology of the UK Renewable Transport Fuel Obligation [68] are conservative (i.e. worst case), but indicate a GHG saving for Argentinean soy biodiesel of 44 percent. This would suggest exclusion from the European biofuel market by 2017 without documentation of good practice. Recent research shows that the European public is only barely aware of biofuel policy [69]. However, if the Renewable Energy Directive does not provide adequate environmental protection, and there is substantial concern among NGOs that this will be the case [70], then public opinion may make it increasingly difficult for soy biodiesel to enter the European market.

The prospect of potentially challenging European market conditions begs the question of whether Argentine soy 
biodiesel could be produced under conditions that are more socially and environmentally benign, in a manner supportive of the local economy and more resilient to international market conditions. It also begs the question of whether large scale, highly mechanised production for soy is almost inevitable and of the role of alternative markets to Europe, be these export, national or local markets. In the short and medium term, it is difficult to envisage local production as described above without preferential legislative and fiscal support: global markets for biodiesel are potentially huge and at the moment it would seem that only the European market is intent on not simply rewarding least-cost production. While this need not prevent different models of production, it will certainly mitigate against them.

We have shown that although the Argentine soy biodiesel supply chain exhibits clustering at both the cultivation and processing levels, it is also dependent on other relationships both nationally and internationally, including research and development linkages with international biotechnology firms. Although the trend of horizontal and vertical integration is advanced and likely to continue, we argue that clustering, in the sense of geographic proximity, can only partly account for the sector's growth. One potential risk for the sector is that European demand may be unreliable in the long term, due to increasingly stringent environmental requirements. On the other hand, any on-going increase in fossil oil prices, and the likelihood of growing demand for transport fuel globally, could underpin demand for Argentine soy biodiesel in the longer term.

Looking at alternative futures, in principle, via cooperatives and farmer associations, biofuels in Argentina offer the potential for restructuring local and regional primary production, potentially making this less centralised and a provider of more widely distributed regional development benefits than the Argentine agro-industrial clusters [28] currently provide. Again in principle, such change could be driven by increasing European public awareness of the environmental and social impacts of current Argentine production patterns. A shift to a higher performing, environmentally and socially certified product, possibly commanding a higher premium, might be possible and would change the nature of the sector considerably. Whatever the shape of the future Argentine biofuels sector it is clear that in order to fully understand its geographical distribution one must look well beyond the locality itself.

\section{ACKNOWLEDGEMENTS}

Funding for this research was provided by the UK Engineering and Physical Sciences Research Council (EPSRC) as part of the Supergen Bioenergy Consortium. The authors would also like to thank all of the Argentine interviewees who assisted with this research.

\section{REFERENCES}

[1] European Commission. Directive 2003/30/EC of the European Parliament and of the Council of 8 May 2003 on the promotion of the use of biofuels or other renewable fuels for transport. Brussels: European Commission 2009.

[2] European Commission. Directive 2009/28/EC of the European Parliament and of the Council of 23 April 2009 on the promotion of the use of energy from renewable sources and amending and subsequently repealing Directives 2001/77/EC and 2003/30/EC. Brussels: European Commission 2009.
[3] Senate and House of Representatives. Energy Independence and Security Act of 2007. Washington DC: US Government Printing Office 2007.

[4] Holt-Gimenez E, Shuttack A. The agrofuels transition: restructuring places and spaces in the global food system. Bull Sci Technol Soc 2009; 29(3): 180-88.

[5] IEA. World Energy Outlook 2008. Paris: International Energy Agency 2008.

[6] Doornbosch R, Steenblik R. Biofuels: is the cure worse than the disease. Paris: OECD 2007.

[7] Sylvester-Bradley R. Critique of Searchinger and related papers assessing indirect effects of biofuels on land use change. London: Renewable Fuels Agency 2008.

[8] Ivanic M, Martin W. Implications of higher global food prices for poverty in low income countries. Washington DC: World Bank 2008.

[9] European Parliament. Texts adopted at the sitting of Wednesday 17 December 2008. P6_TA-PROV (2008)12-17. European Parliament, Brussels, 2008. Available from: http://www.euractiv.com/en/ climate-change/mixed-reactions-parliament-approves-eu-climatedeal/article-178163 [cited: Dec 2009].

[10] Renewable Fuels Agency. The Gallaher review of the indirect effects of biofuels production. St Leonards-on-Sea: RFA 2008.

[11] Hopkins TK, Wallerstein I. Commodity chains in the world economy prior to 1800 . Review 1986; 10(1): 157-70.

[12] Gerreffi G, Korzeniewicz M, Eds. Commodity chains and global capitalism. westport. CT: Praeger Press 1994.

[13] Henderson J, Dicken P, Hess M, Coe N, Yeung HWC. Global production networks and the analysis of economic development. Rev Int Pol Econ 2002; 9: 436-64.

[14] Coe NM, Rob K, Nigel T, Eds. Global production networks: realising the potential. International Encyclopaedia of Human Geography. Oxford: Elsevier 2009.

[15] Gwynne RN. Globalisation, commodity chains and fruit exporting regions in Chile. J Econ Soc Geog 1999; 29(2): 211-25.

[16] Gibbon P. Upgrading primary production: a global commodity chain approach. World Dev 2001; 29(2): 345-36.

[17] Lockie S, Kitto S. Beyond the farm gate: production-consumption networks and agri-food research. Soc Rur 2000; 40(1): 3-19.

[18] Niles D, Roff R. Shifting agrifood systems: the contemporary geography of food and agriculture: an introduction. Geo J 2008; 73(1): 1-10.

[19] Imbruce V. The production relations of contract farming in Honduras. Geo J 2008; 73(1): 67-82.

[20] Adam G, Schvaneveldt J. Understanding research methods. $2^{\text {nd }}$ ed. London: Longman 1991.

[21] Mouton J. Understanding social research. Pretoria: Van Schaik 1996.

[22] Zikmund W. Business research methods, 6th edition. New York: Dryden Press 2000.

[23] Tomei J, Upham P. Argentinean soy-based biodiesel: an introduction to production and impacts. Energy Policy 2009; 37(10): 3890-8.

[24] Upham P, Thornley P, Tomei J, Boucher P. Substitutable biodiesel feedstocks for the UK: a review of sustainability issues with reference to the UK RTFO. J Clean Prod 2009; 17(S1): S37-S45.

[25] Johnston M, Holloway T. A global comparison of national biodiesel production potentials. Environ Sci Technol 2007; 41(23): 7967-673.

[26] Garff D, Correnti N. Argentina: key players in the biofuels market. Buenos Aires: Cámara Argentino Alemania 2009.

[27] FAO 2009. FAOStats. Food and Agriculture Organisation, Rome. Available from: http://faostat.fao.org/defaultaspx [cited: Dec 2009].

[28] USDA. Agriculture in Brazil and Argentina: developments and prospects for major field crops. USDA 2001.

[29] The Economist. Argentina: history in brief. Country briefings: Argentina. Economist 2005.

[30] Waisman C. Argentina: capitalism and democracy. In: Diamond L, Hartlyn J, Linz J, Lipset S, Eds. Democracy in developing countries: Latin America. Boulder: Lynne Rienner Publishers 1999.

[31] MacEwan A. Economic debacle in Argentina: the IMF strikes again. Third World Resurgence Magazine 2002; pp. 137-8.

[32] SAGPyA. Régimen de Regulación y Promoción para la Producción y Uso Sustentable de Biocombustibles, Law No. 26.093/06, Buenos Aires: SAGPyA 2006. 
[33] CAdER. Outlook for the Argentine biodiesel industry. Buenos Aires: Cámara Argentina de Energía Renovable 2008.

[34] Van Dam J, Faaij APC, Hilbert J, Petruzzi H, Turkenburg WC. Large-scale bioenergy production from soybeans and switchgrass in Argentina: part B. Environmental and socio-economic impacts on a regional level. Ren Sust En Rev 2009; 13(8): 1679-709.

[35] SAGPyA. Perspectivas de los biocombustibles en la Argentina y en Brasil. Buenos Aires: Secretaria de Agricultura Ganadería Pesca y Alimentación 2005

[36] Biodiesel.com.ar, 2010. Argentina: el biodiesel a la espera de un precio lógico. NextFuel, Buenos Aires. Available from: http://biodiesel.com.ar [cited: Jan 2010].

[37] Rathi AM, Natarajan B. Understanding the soybean crush. Commodity Watch 2008; 1(2): 1-3.

[38] Galeano, E. Open veins of Latin America: five centuries of the pillage of a continent. London: Serpent's Tail 1971

[39] SIIA, 2010. Series y estadísticas relacionadas a cultivos. Sistema Integrado de Información Agropecuaria, Buenos Aires. Available from: http://www.siia.gov.ar/ [cited: June 2010].

[40] Corn and Soybean Digest, 2009. Record South American soy crop possible. Corn and Soybean Digest Minneapolis. Available from: http://cornandsoybeandigest.com/soybeans/brazil/0721-soy-croprecord-possible/ [cited: Jan 2010].

[41] Pozzolo OR, Ferrari HJ, Hidalgo J, Curro C. Perdidas del grano de maíz en transporte por carretera. Buenos Aires: EEA INTA 2007.

[42] Ramamurti R. Testing the limits of privatisation: Argentine railroads. World Dev 1997; 25(12): 1973-93.

[43] Franco D. Logística en la cadena de oleaginosas. SAGPyA, Buenos Aires. Available from: http://www.alimentosargentinos.gov.ar/03/revistas/r_30/articulos/Logistica_oleaginosas.htm [cited: June 2010].

[44] USDA. Argentina's soybean complex competitiveness. Washington DC: US Department of Agriculture 2006.

[45] USDA. World agricultural supply and demand estimates. Washington DC: US Department of Agriculture 2010.

[46] Mathews JA, Goldsztein H. Capturing latecomer advantages in the adoption of biofuels: the case of Argentina. Energy Policy 2009; 37(1): 326-37.

[47] CAdER. State of the Argentine biodiesel industry. Buenos Aires: Cámara Argentina de Energía Renovable 2010.

[48] USB. The negative impact of Argentina's differential export taxes on United States soybean producers and processors. Chesterfield, MO: United Soybean Board 2010.

[49] Van Dam J, Faaij APC, Hilbert J, Petruzzi H, Turkenburg WC. Large-scale bioenergy production from soybeans and switchgrass in Argentina: part A. Potential and economic feasibility for national and international markets. Ren Sust En Rev 2009; 13(8): 1710-33..

[50] CAdER. State of the Argentine biodiesel industry: first semester 2009 report. Buenos Aires, Cámara Argentina de Energía Renovables 2009.

[51] Biofuels Platform. Production of biodiesel in the world, 2008. Lausenne: Biofuels Platform, 2010. Available from: http://www.biofuels-platform.ch/en/infos/production.php?id=biodie sel. [cited: June 2010].

[52] Reuters. German biodiesel output collapses. Reuters, Hamburg. Available from: http://www.reuters.com/article/idUSL1589672020 080115 [cited: Sept 2009].

[53] Lamers P, McCormick K, Hilbert J. The emerging liquid biofuel market in Argentina: implications for domestic demand and international trade. Energy Pol 2008; 36(4): 1479-90.

[54] Giarracca N, Teubal M, Eds. El campo argentino en la encrucijada: estrategias y resistencias sociales, ecos en la ciudad. Buenos Aires: Alianza Editorial 2005.

[55] Corregido EM. A speech to the Argentine senate, July 2008.

[56] INTA. Documento base: programa nacional de bioenergía. Buenos Aires: Instituto Nacional de Tecnología Agropecuaria 2008.

[57] Varela L, Bisang R. Biotechnology in Argentine agriculture faces worldwide concentration. Elec J Biotech 2006; 9(3): 227-31.

[58] Grau HR, Gasparri NI, Aide TM. Agriculture expansion and deforestation in seasonally dry forests of north-west Argentina. Env Cons 2005; 32(2): 140 - 148

[59] Panichelli L, Dauriat A, Gnansounou E. Life cycle assessment of soybean based biodiesel in Argentina for export. Int J LCA 2009; 14: 144-59.

[60] Zak MR, Cabido M, Caceres D. What drives accelerated land cover change in central Argentina? Synergistic consequences of climatic, socio-economic and technological factors. Env Mgt 2008; 42: 1819.

[61] Viglizzo EF, Roberto ZE, Lértora F, Gay EL, Bernardos J. Climate and land-use change in field crop ecosystems of Argentina. Agric Ecos Env 1997; 66(1): 61-70.

[62] Forjan HJ, Zamora M, Bergh R, Manso ML, Seghezzo MI, Mofese ER. Impacto de la inclusión de la soja en secuencias agrícolas de sur bonaerense: el balance de nutrientes. Tres Arroyos: EEA INTA 2006.

[63] GRR. Pueblos fumigados: informe sobre la problemática del uso de plaguicidas en las principales provincias sojeras de la Argentina. Buenos Aires: GRR 2009.

[64] Semino S. Can certification stop high soy pesticide use? Pest News 2008; 82: 9-11.

[65] Kvakkestad V. Institutions and the R\&D of GM crops. Ecol Econ 2009; 68(10): $2688-695$.

[66] Anon. A seedy practice. Sci Perspec 2009; 201(2): 28

[67] ActionAid. Power hungry: six reasons to regulate global food corporations. London: ActionAid 2005.

[68] RFA. Carbon and sustainability reporting within the Renewable Transport Fuel Obligation: technical guidance part 1. St Leonardson-Sea: RFA 2009.

[69] FoE England and Wales. Public in the dark about biofuels in their petrol. London: Friends of the Earth 2008.

[70] Upham P, Tomei J. Critical stakeholder perceptions of carbon and sustainability reporting in the UK Renewable Transport Fuel Obligation. Manchester: Tyndall Centre 2010.

(c) Tomei and Upham; Licensee Bentham Open.

This is an open access article licensed under the terms of the Creative Commons Attribution Non-Commercial License (http://creativecommons.org/licenses/by$\mathrm{nc} / 3.0 /$ ) which permits unrestricted, non-commercial use, distribution and reproduction in any medium, provided the work is properly cited. 